\title{
PENERAPAN METODE ANALYTICAL HIERARCHY PROCESS UNTUK PEMILIHAN KARYAWAN TERBAIK PADA PT. RADIO ELSHINTA
}

\author{
Ary Maulana Pratama ${ }^{1)}$, Rusdah ${ }^{2)}$ \\ ${ }^{1}$ Sistem Informasi, Fakultas Teknologi Informasi, Universitas Budi Luhur \\ ${ }^{1,2} \mathrm{Jl}$. Raya Ciledug, Petukangan Utara, Kebayoran Lama, Jakarta Selatan 12260 \\ E-mail : arymaulanapratama@gmail.com ${ }^{1)}$, rusdah@budiluhur.ac.id $^{2)}$
}

\begin{abstract}
Abstrak
Kinerja karyawan yang tidak stabil sangat mempengaruhi hasil yang ingin dicapai perusahaan. PT. Radio Elshinta merupakan perusahaan yang bergerak di bidang jaringan radio siaran Indonesia yang berpusat di Jakarta, dimana perusahaan tersebut menyiarkan berita dan informasi yang aktual. Masalah yang terdapat dalam mengadakan sistem pemilihan karyawan terbaik adalah belum adanya bobot keriteria dan subkriteria beserta metode dalam pemilihan karyawan terbaik, sehingga sulit untuk menentukan karyawan terbaik yang tepat dan akurat. Penelitian ini bertujuan untuk membangun sistem penunjang keputusan pemilihan karyawan terbaik dengan menerapkan metode Analytical Hierarchy Process (AHP). Penghitungan bobot subkriteria pada kriteria Personal skill yang dihasilkan dalam penelitian ini adalah Subkriteria Kreativitas dan inisiatif serta fleksibilitas 3,87\%, kemampuan berfikir secara rasional dan kemauan untuk maju 28,78\%, Disiplin kerja dan rasa tanggung jawab dalam melaksanakan tugas 17,52\%, kemampuan berkomunikasi dan bekerja sama 8,52\%, Kerajinan, ketekunan, kerapihan, kejujuran, \& loyal dalam melaksanakan pekerjaan 17,59\%, Kedewasaan, hormat kepada atasan dan stabilitas 8,7\%, Rasa memiliki perusahaan 15,01\% dengan hasil uji Consistency Ratio (CR) sebesar 0,0502. Sistem penunjang keputusan ini dibuat untuk memberikan informasi yang lebih jelas sehingga dapat memudahkan HRD Manager untuk memproses pemilihan karyawan terbaik pada PT. Radio Eshinta.
\end{abstract}

Kata kunci: Sistem Penunjang Keputusan, Karyawan, AHP

\section{PENDAHULUAN}

PT. Radio Elshinta merupakan perusahaan yang berlokasi di JL. Joglo Raya No. 70, RT.04/RW.06, Joglo, Kembangan, Kota Jakarta Barat. PT. Radio Elshinta merupakan perusahaan yang bergerak di bidang jaringan radio siaran Indonesia yang berpusat di Jakarta, dimana perusahaan tersebut menyiarkan berita dan informasi yang aktual. Karena itu PT.Radio Elshinta harus memiliki karyawan yang berkualitas agar dapat mencapai target perusahaan, oleh karena itu pihak PT. Radio Elshinta berupaya untuk melakukan pemilihan karyawan terbaik agar dapat meninjau kualitas karyawan tersebut. Serta untuk meningkatkan motivasi karyawan untuk melakukan perkerjaannya dengan sebaik mungkin. Tetapi teradpat kesulitan untuk HRD Manajer dalam menentukan karyawan terbaik dikarenakan perhitungan penilaian karyawan terbaik masih menggunakan Microsoft Excel, dan belum adanya bobot pada setiap kriteria dan subkriteria, sehingga adanya kesamaan jumlah perhitungan nilai karyawan.

Beberapa penelitian telah dilakukan menggunakan metode Analytical Hierarchy Process (AHP) dalam pemilihan karyawan terbaik. Kriteria yang digunakan 3 (tiga), yaitu : Permi Pertama (PP), Uang Pertanggungan (UP), dan Surat Permintaan (SP) yang menghasil karyawan terbaik adalah Rinta
Wanti dengan Nilai Total 1.00 [1]. Penelitian lain menggunakan metode AHP dan TOPSIS dengan memiliki 5 (lima) kriteria, yaitu: pengetahuan, kemampuan, sikap, absensi, dan kerjasama dengan menghasil 3 (tiga) ranking terbesar yaitu : Hilman Bakhtiar 0.9549, Basuki Cahyo Setyo 0.9126, dan Dimas Haryandia 0.8276 [2]. Penelitian lain menggunakan AHP dengan memiliki 5 (lima) kriteria, yaitu: hasil checking, jam kerja, shift kerja, data afkir, dan data klaim dengan hasil karyawan terbaiknya adalah Yansen dengan nilai akhirnya 0.251 [3].

\section{METODE PENELITIAN}

\subsection{Sistem Penunjang Keputusan}

Sistem Penunjang Keputusan (SPK) dapat diartikan sebagai sistem yang berguna untuk memberikan pemecahan masalah. Namun secara khusus didefinisikan sebagai sistem yang membantu pekerjaan seorang manajer dalam memecahkan suatu masalah dengan memberi informasi pada keputusan tertentu [4].

\subsection{Tahapan Penelitian}

Ada 14 (empat belas) tahapan penelitian yang dilakukan pada Gambar 1, yaitu : 


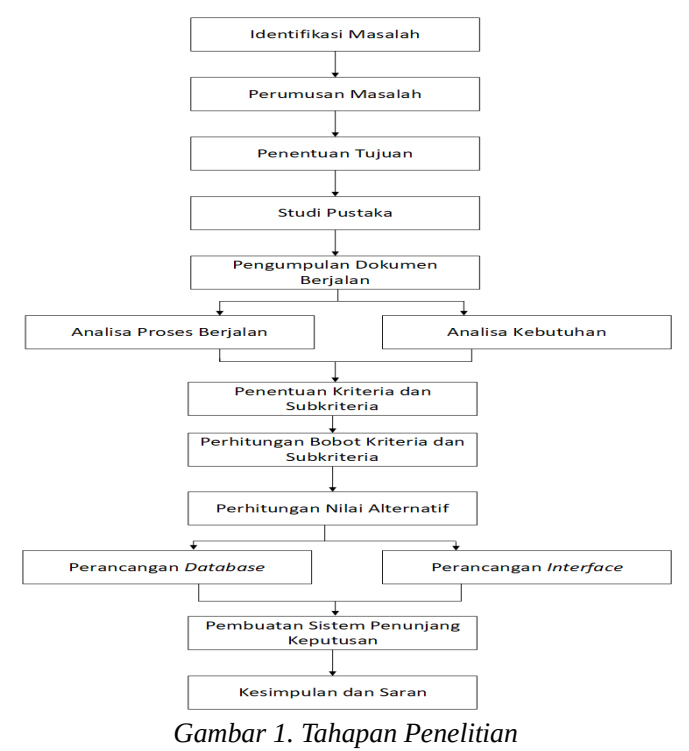

Pertama, melakukan identifikasi masalah dengan cara melakukan wawancara kepada HRD Manajer, yang bertujuan untuk mengetahui masalah yang terdapat saat HRD Manajer melakukan pemilihan karyawan terbaik pada PT. Radio Elshinta.

Kedua, melakukan perumusan masalah dengan cara membuat fishbone diagram berdasarkan informasi yang sudah dijelaskan oleh HRD Manajer.

Ketiga, menentukan tujuan penelitian yang bertujuan untuk memfokuskan pencapaian dalam penelitian tersebut.

Keempat, melakukan studi pustaka dengan cara mengumpulkan e-book, jurnal, buku artikel, dan literature yang berhubungan dengan penelitian.

Kelima, melakukan pengumpulan dokumen berjalan dengan cara mengumpulkan dokumendokumen yang berhubungan dengan penelitian supaya memudahkan dalam pembuatan sistem.

Keenam, melakukan analisa proses berjalan dengan cara membuat activity diagram yang bertujuan untuk menggambarkan alur proses yang ada.

Ketujuh, melakukan analisa kebutuhan dengan cara membuat use case diagram yang bertujuan untuk membuat rancangan interface pada sistem.

Kedelapan, menentukan kriteria dan subkriteria yang dapat digunakan dalam pemilihan karyawan terbaik pada PT. Radio Elshinta.

Kesembilan, melakukan perhitungan kriteria dan subkriteria dengan cara membuat kuesioner perbandingan kepentingan antar kriteria dan subkriteria yang diisi oleh HRD Manajer PT. Radio Elshinta.

Kesepuluh, melakukan perhitungan nilai alternatif dengan cara menggunakan metode Analytical Hierarchy Process (AHP) .
Kesebelas, merancang database dengan cara membuat Entity Relationship Diagram (ERD) supaya terciptanya rancangan basis data yang terintegrasi.

Keduabelas, merancang interface dengan menggunakan Microsoft Visio berdasarkan use case diagram yang dibikin sebelumnya.

Ketigabelas, membuat sistem penunjang keputusan pemilihan karyawan terbaik dengan menggunakan bahasa pemrograman JAVA.

Keempatbelas, membuat kesimpulan dan saran yang bertujuan untuk menjawab masalah yang ada.

\section{HASIL DAN PEMBAHASAN}

\subsection{Profil Organisasi}

PT. Radio Elshinta merupakan perusahaan yang berlokasi di JL. Joglo Raya No. 70, RT.04/RW.06, Joglo, Kembangan, Kota Jakarta Barat. PT. Radio Elshinta merupakan perusahaan yang bergerak di bidang jaringan radio siaran Indonesia yang berpusat di Jakarta, dimana perusahaan tersebut menyiarkan berita dan informasi yang aktual.

PT. Radio Elshinta memiliki visi yaitu Menjadi radio terbaik dan terpercaya, dengan menyampaikan berita dan informasi yang dapat memberikan pencerahan, keterbukaan dan demokrasi yang bertanggung jawab bagi masyarakat luas khususnya di Kota Jakarta dan sekitarnya. Untuk mencapai visi tersebut PT. Radio Elshinta memiliki misi, yaitu :

1) Memberikan pemcerahan bagi masyarakat luas dan masyarakat kota Jakarta dan sekitarnya pada khususnya dengan memberikan informasi dan berita yang penting, aktual dan bermanfaat.

2) Menciptakan keterbukaan berita dan informasi bagi masyarakat dengan tetap mengedepankan etika jurnalistik, tidak berunsur SARA, menjunjung nilai demokrasi, moral agama, dan bertanggung jawab.

3) Berupaya mencerdaskan kehidupan bangsa melalui siaran program berita dan informasi yang berkualitas.

\subsection{Proses Bisnis Berjalan}

Dalam setiap pemilihan karyawan terbaik, staf HRD akan mencetak form penilaian prestasi karyawan. Setelah itu, staf HRD akan memberikan form penilaian kepada HRD manajer untuk diisi. Kemudian HRD manajer mengisi form penilaian prestasi karyawan dan menyerahkan kepada staf HRD, setelah itu staf HRD melakukan penghitungan hasil penilaian dengan menggunakan Microsoft Excel. Setelah proses penghitungan selesai, staf HRD memberikan hasil penghitungan kepada HRD manajer. Kemudian HRD manajer akan menentukan karyawan yang terpilih menjadi karyawan terbaik. 


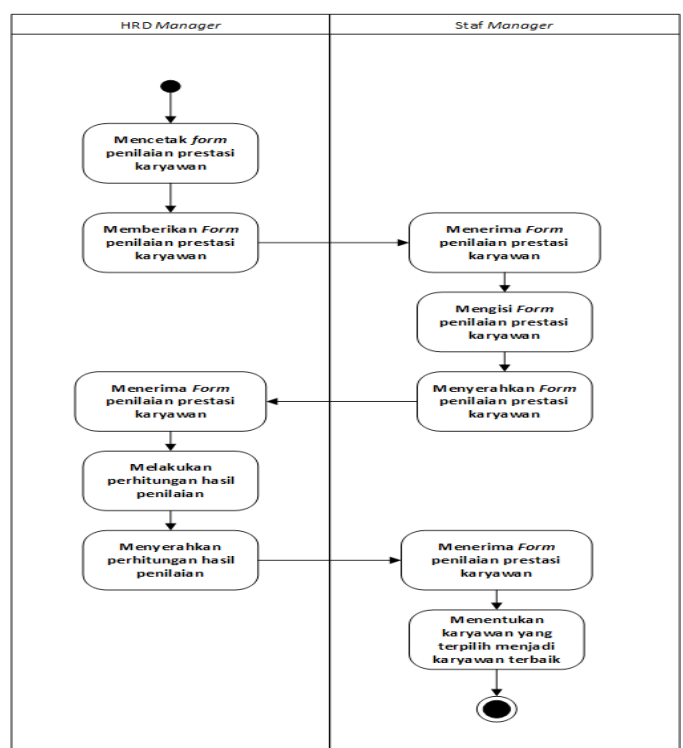

Gambar 2. Activity Diagram Proses Pemilihan Karyawan Terbaik

\subsection{Analisa Masalah}

Dalam menganalisa masalah pemilihan karyawan terbaik dengan menggunakan Fishbone Diagram (Gambar 3) terdapat 3 (tiga) kategori permasalahan yaitu proses, tempat, dan metode.

Dalam kategori proses terdapat masalah lamanya dalam menentukan nilai kinerja karyawan, karena disebabkan proses perhitungan data nilai masih secara manual. Dan terjadinya kerancuan dalam pengambilan keputusan, karena disebabkan oleh terdapatnya kesamaan dalam jumlah penilaian.

Dalam kategori metode terdapat masalah dalam pengambilan keputusan kurang tepat, karena disebabkan belum adanya nilai pembobotan dalam pada setiap kriteria dan subkriteria.

Dalam kategori tempat terdapat masalah lamanya pencarian data nilai kinerja karyawan, karena disebabkan oleh data nilai kinerja karyawan masih dalam bentuk arsip.

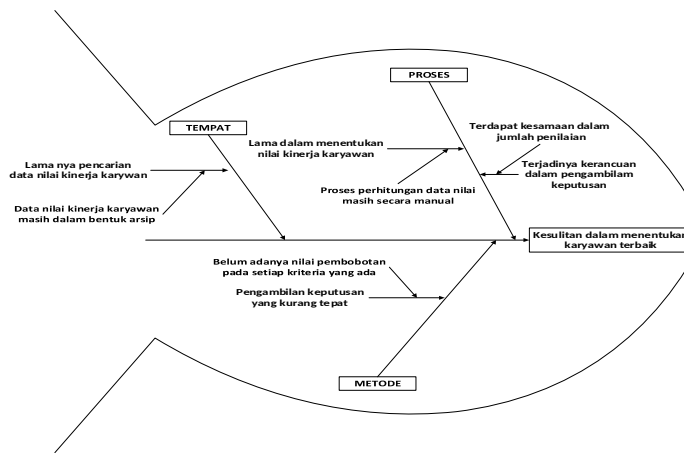

Gambar 3. Fishbone Diaaram

\subsection{Model Metode Analytical Hierarchy} Process

Berikut betuk struktur hirarki pemilihan karyawan terbaik pada PT. Radio Elshinta dengan 2 (dua) kriteria, 9 (Sembilan) subkriteria, dan beberapa alternatif seperti pada gambar 4 .

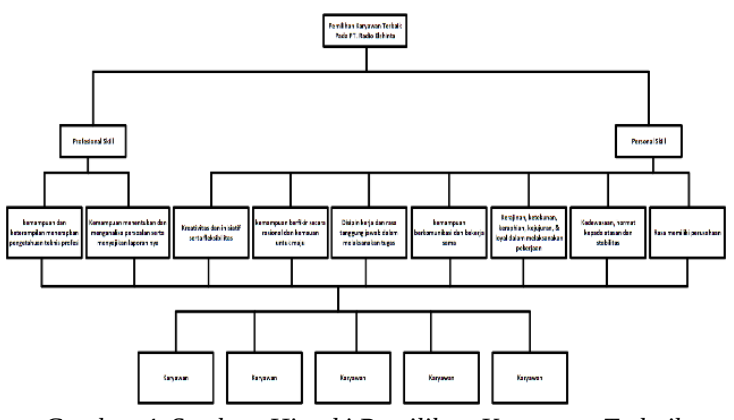

Gambar 4. Struktur Hirarki Pemilihan Karyawan Terbaik

\subsection{Perbandingan Kepentingan Antar Kriteria}

Nilai perbandingan kepentingan antar kriteria didapat berdasarkan kuesioner yang diajukan kepada responden yaitu HRD Manajer pada PT. Radio Elshinta, berikut tampilan antar kriteria dalam tabel 1.

Tabel 1. Perbandingan Kepentingan Antar Kriteria

\begin{tabular}{lll}
\hline Kriteria & Professional Skill & Personal Skill \\
\hline Professional Skill & $1 / 1$ & $3 / 1$ \\
Personal Skill & $1 / 3$ & $1 / 1$ \\
\hline
\end{tabular}

\subsection{Perbandingan Kepentingan Antar} Subkriteria

Nilai perbandingan kepentingan antar subkriteria didapat berdasarkan kuesioner yang diajukan kepada responden, berikut tampilan antar subkriteria dalam bentuk tabel matriks pada tabel 3 dan tabel 4.

Tabel 2. Tabel Subkriteria

\begin{tabular}{|c|c|c|}
\hline Kriteria & $\begin{array}{c}\text { Kode } \\
\text { Sublkriteria }\end{array}$ & Nama Subkriteria \\
\hline \multirow{2}{*}{$\begin{array}{l}\text { Profesional } \\
\quad \text { Skill }\end{array}$} & SK01 & $\begin{array}{l}\text { kemampuan dan keterampilan } \\
\text { menerapkan pengetahuan teknis profesi }\end{array}$ \\
\hline & SK02 & $\begin{array}{c}\text { Kemampuan menentukan dan } \\
\text { menganalisa persoalan serta menyajikan } \\
\text { laporannya }\end{array}$ \\
\hline \multirow{7}{*}{$\begin{array}{l}\text { Personal } \\
\text { Skill }\end{array}$} & SK03 & Kreativitas dan inisiatif serta fleksibilitas \\
\hline & SK04 & $\begin{array}{c}\text { kemampuan berfikir secara rasional dan } \\
\text { kemauan untuk maju }\end{array}$ \\
\hline & SK0S & $\begin{array}{c}\text { Disiplin kerja dan rasa tanggung jawab } \\
\text { dalam melaksanakan tugas }\end{array}$ \\
\hline & SK06 & $\begin{array}{l}\text { kemampuan berkomunikasi dan bekerja } \\
\text { sama }\end{array}$ \\
\hline & SK07 & $\begin{array}{c}\text { Kerajinan, ketekunan, kerapihan, } \\
\text { kejujuran, \& loyal dalam melaksanakan } \\
\text { pekerjaan }\end{array}$ \\
\hline & SK08 & $\begin{array}{c}\text { Kedewasaan, hormat kepada atasan dan } \\
\text { stabilitas }\end{array}$ \\
\hline & SK09 & Rasa memiliki perusahaan \\
\hline
\end{tabular}


Tabel 3. Perbandingan Kepentingan Antar Subkriteria Pada Kirteria Profesional Skill

\begin{tabular}{lll}
\hline Subkriteria & SK01 & SK02 \\
\hline SK01 & $1 / 1$ & $4 / 1$ \\
SK02 & $1 / 4$ & $1 / 1$ \\
\hline
\end{tabular}

Tabel 4. Perbandingan Kepentingan Antar Subkriteria Pada Kirteria Personal Skill

\begin{tabular}{|l|l|l|l|l|l|l|l|}
\hline $\begin{array}{l}\text { Subkrite } \\
\text { ria }\end{array}$ & $\begin{array}{l}\text { SK } \\
\mathbf{0 3}\end{array}$ & $\begin{array}{l}\text { SK } \\
\mathbf{0 4}\end{array}$ & $\begin{array}{l}\text { SK } \\
\mathbf{0 5}\end{array}$ & $\begin{array}{l}\text { SK } \\
\mathbf{0 6}\end{array}$ & $\begin{array}{l}\text { SK } \\
\mathbf{0 7}\end{array}$ & $\begin{array}{l}\text { SK } \\
\mathbf{0 8}\end{array}$ & $\begin{array}{l}\text { SK } \\
\mathbf{0 9}\end{array}$ \\
\hline SK03 & $1 / 1$ & $1 / 6$ & $1 / 5$ & $1 / 3$ & $1 / 4$ & $1 / 2$ & $1 / 3$ \\
\hline SK04 & $6 / 1$ & $1 / 1$ & $3 / 1$ & $2 / 1$ & $2 / 1$ & $3 / 1$ & $2 / 1$ \\
\hline SK05 & $5 / 1$ & $1 / 3$ & $1 / 1$ & $2 / 1$ & $1 / 1$ & $2 / 1$ & $2 / 1$ \\
\hline SK06 & $3 / 1$ & $1 / 2$ & $1 / 2$ & $1 / 1$ & $1 / 2$ & $1 / 2$ & $1 / 2$ \\
\hline SK07 & $4 / 1$ & $1 / 2$ & $1 / 1$ & $2 / 1$ & $1 / 1$ & $2 / 1$ & $2 / 1$ \\
\hline SK08 & $2 / 1$ & $1 / 3$ & $1 / 2$ & $2 / 1$ & $1 / 2$ & $1 / 1$ & $1 / 4$ \\
\hline SK09 & $3 / 1$ & $1 / 2$ & $1 / 2$ & $2 / 1$ & $1 / 2$ & $4 / 1$ & $1 / 1$ \\
\hline
\end{tabular}

\subsection{Pengujian Metode Analytical Hierarchy} Process (AHP)

Pengujian metode AHP pada perbandingan kepentingan antar subkriteria pada kriteria Personal Skill dilakukan dengan cara menghitung nilai Consistency Index (CI) dengan rumus (1).

$$
\begin{gathered}
\mathrm{CI}=\frac{(\pi-\mathrm{n})}{\mathrm{n}-1} \\
n=\text { Banyak alternatif } \\
\mathrm{CI}=\frac{(7,3975-7)}{7-1}=0,0662
\end{gathered}
$$

Setelah mendapatkan nilai CI, maka lanjut mencari Consistency Ratio (CR) dengan rumus (2) dan nilai Random Index (RI) untuk $\mathrm{n}=7$ adalah 1,32, dan didapat dari tabel Oarkridge.

$$
\begin{gathered}
C R=R I \\
C R=\frac{C, 0662}{1,32}=0,0502
\end{gathered}
$$

\subsection{Perhitungan Nilai Alternatif}

Berikut adalah alternatif yang digunakan dalam pemilihan karyawan terbaik pada PT. Radio Elshinta.

Tabel 5. Tabel Alternatif

\begin{tabular}{|l|c|c|c|c|c|c|c|c|c|}
\hline \hline \multicolumn{1}{|c|}{ Alternatif } & SK & SK & SK & SK & SK & SK & SK & SK & SK \\
& 01 & 02 & 03 & 04 & 05 & 06 & 07 & 08 & 09 \\
\hline Arief Anditantyo & 8 & 7 & 9 & 9 & 8 & 9 & 7 & 8 & 9 \\
\hline Setiadi Agung Sukarno & 7 & 8 & 7 & 8 & 9 & 7 & 8 & 9 & 9 \\
\hline Oddy Yudha Pratama & 9 & 7 & 8 & 7 & 9 & 8 & 7 & 7 & 8 \\
\hline Jaenal Abidin & 8 & 9 & 9 & 8 & 7 & 9 & 9 & 8 & 7 \\
\hline Zukri Akmal & 7 & 9 & 7 & 9 & 7 & 7 & 8 & 7 & 7 \\
\hline \hline
\end{tabular}

\subsection{Perangkingan Alternatif}

Nilai eignvector per subkriteria dari setiap alternatif yang sudah didapatkan sebelumnya kemudian dihitung untuk mendapatkan nilai akhir dari masing-masing alternatif.

Tabel 6. Matriks Perhitungan Nilai Alternatif

\begin{tabular}{|l|l|l|l|l|l|l|l|l|l|}
\hline Alternatif & SK01 & SK02 & SK03 & SK04 & SK05 & SK06 & SK07 & SK08 & SK09 \\
\hline $\begin{array}{l}\text { Arief } \\
\text { Anditantyo }\end{array}$ & 0.2051 & 0.1750 & 0.2250 & 0.2195 & 0.2000 & 0.2250 & 0.1795 & 0.2051 & 0.2250 \\
\hline $\begin{array}{l}\text { Setiadi } \\
\text { Agung } \\
\text { Sukarno }\end{array}$ & 0.1795 & 0.2000 & 0.1750 & 0.1951 & 0.2250 & 0.1750 & 0.2051 & 0.2308 & 0.2250 \\
\hline $\begin{array}{l}\text { Oddy } \\
\text { Yudha } \\
\text { Pratama }\end{array}$ & 0.2308 & 0.1750 & 0.2000 & 0.1707 & 0.2250 & 0.2000 & 0.1795 & 0.1795 & 0.2000 \\
\hline $\begin{array}{l}\text { Jaenal } \\
\text { Abidin }\end{array}$ & 0.2051 & 0.2250 & 0.2250 & 0.1951 & 0.1750 & 0.2250 & 0.2308 & 0.2051 & 0.1750 \\
\hline $\begin{array}{l}\text { Zukri } \\
\text { Akmal }\end{array}$ & 0.1795 & 0.2250 & 0.1750 & 0.2195 & 0.1750 & 0.1750 & 0.2051 & 0.1795 & 0.1750 \\
\hline Bobot & 0,8000 & 0,2000 & 0,0387 & 0,2878 & 0,1752 & 0,0852 & 0,1759 & 0,0870 & 0,1501 \\
\hline
\end{tabular}

1) Arief Anditantyo

$=\{(0,2051 * 0,8000)+(0,1750 * 0,2000)+(0,2250$ $* 0,0387)+(0,2195 * 0,2878)+(0,2000 * 0,1752)$ $+(0,2250 * 0,0852)+(0,1795 * 0,1759)+(0,2051$ $* 0,0870)+(0,2250 * 0,1501)\}$

$=0,4084$

2) Setiadi Agung Sukarno

$=\{(0,1795 * 0,8000)+(0,2000 * 0,2000)+(0,1750$ $* 0,0387)+(0,1951 * 0,2878)+(0,2250 * 0,1752)$ $+(0,1750 * 0,0852)+(0,2051 * 0,1759)+(0,2308$ $* 0,0870)+(0,2250 * 0,1501)\}$

$=0,3908$

3) Oddy Yudha Pratama

$=\{(0,2308 * 0,8000)+(0,1750 * 0,2000)+(0,2000$ $* 0,0387)+(0,1707 * 0,2878)+(0,2250 * 0,1752)$ $+(0,2000 * 0,0852)+(0,1795 * 0,1759)+(0,1795$ $* 0,0870)+(0,20000 * 0,1501)\}$

$=0,4101$

4) Jaenal Abidin

$=\{(0,2051 * 0,8000)+(0,2250 * 0,2000)+(0,2250$ $* 0,0387)+(0,1951 * 0,2878)+(0,1750 * 0,1752)$ $+(0,2250 * 0,0852)+(0,2308 * 0,1759)+(0,2051$ $* 0,0870)+(0,1750 * 0,1501)\}$

$=0,4085$

5) Zukri Akmal

$=\{(0,1795 * 0,8000)+(0,2250 * 0,2000)+(0,1750$ $* 0,0387)+(0,2195 * 0,2878)+(0,1750 * 0,1752)$ $+(0,1750 * 0,0852)+(0,2051 * 0,1759)+(0,1795$ $* 0,0870)+(0,1750 * 0,1501)\}$

$=0,3821$

Dari penghitungan nilai akhir di atas, didapatkan hasil perangkingan karyawan seperti pada tabel 7 . 
Tabel 7. Hasil Perangkingan Karyawan

\begin{tabular}{lll}
\hline Rank & Nama Karyawan & Nilai Akhir \\
\hline 1 & Oddy Yudha Pratama & 0,4101 \\
2 & Jaenal Abidin & 0,4085 \\
3 & Arief Anditantyo & 0,4084 \\
4 & Setiadi Agung Sukarno & 0,3908 \\
5 & Zukri Akmal & 0,3821 \\
\hline
\end{tabular}

\subsection{Model Basis Data}

Model basis data ini dirancang bertujuan untuk pengembangan yang akan diterapkan oleh sistem, dirancang dalam Entity Relationship Diagram (ERD).

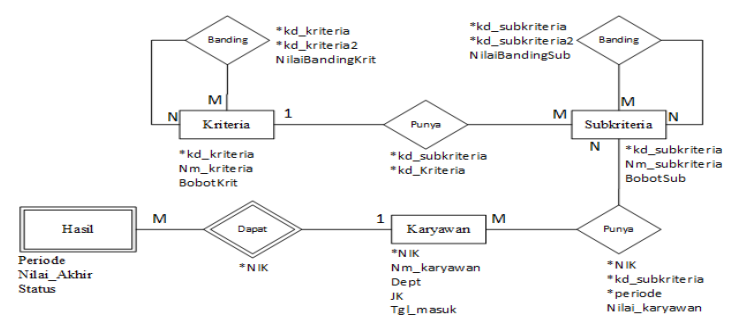

Gambar 5. Entity Relationship Diagram (ERD)

\subsection{Use Case Diagram}

Use Case Diagram adalah diagram yang berfungsi untuk membatu menggambarkan kebutuhan pada sistem.

1. Use Case Diagram Input

Use Case Diagram Input (Gambar 6) terdapat aktivitas Entri Data Karyawan, Entri Data Kriteria, dan Entri Subkriteria.

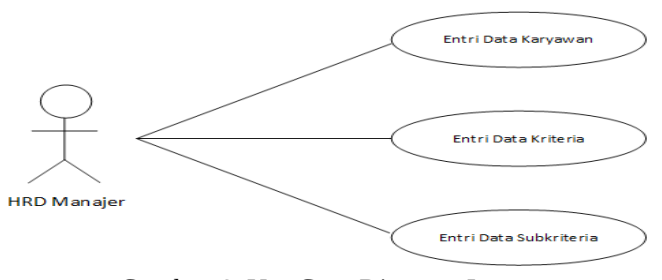

Gambar 6. Use Case Diagram Input

\section{Use Case Diagram Proses}

Use Case Diagram Proses (Gmbar 7) terdapat aktivitas Entri Nilai Perbandingan Kriteria, Entri Nilai Perbandingan Subkriteria, Entri Nilai Alternatif, Perhitungan Nilai Alternatif, dan Entri Hasil Keputusan.

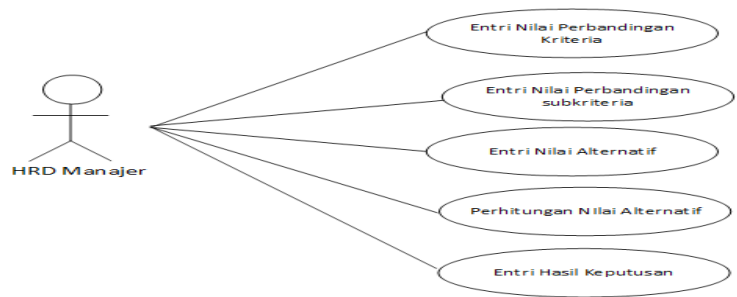

Gambar 7. Use Case Diagram Proses
3. Use Case Diagram Laporan

Use Case Diagram Laporan (Gambar 8) terdapat aktivitas Cetak Hasil Keputusan dan Cetak Laporan Kinerja Karyawan.

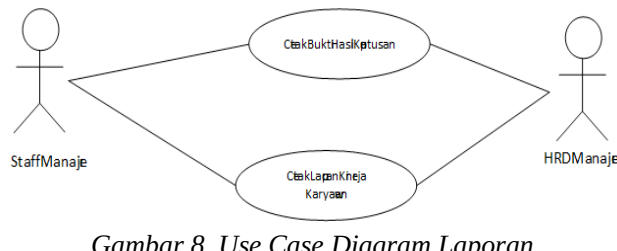

\subsection{Rancangan Layar}

Pada rancangan layar sistem penunjang keputusan diawali dengan menu utama (Gambar 9), dibagian menu utama terdapat 3 kategori yaitu input, proses, dan laporan, dimana masing-masing kategori tersebut terdapat subkategori.

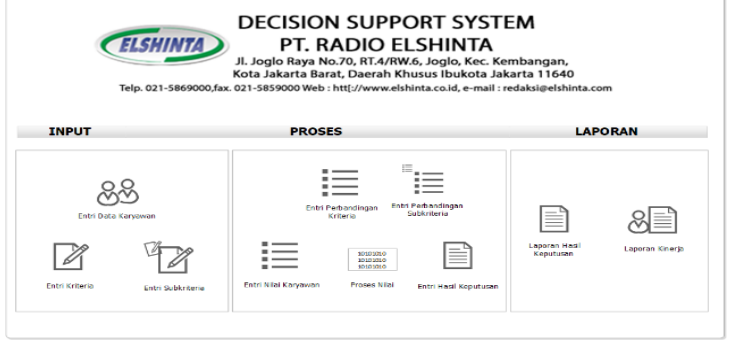

Gambar 9. Rancangan Layar Menu Utama

Form Entry Karyawan (Gambar 10) terdapat pada menu input dibagian menu utama, form ini digunakan untuk menginput data karyawan yang ada di PT. Radio Elshinta.

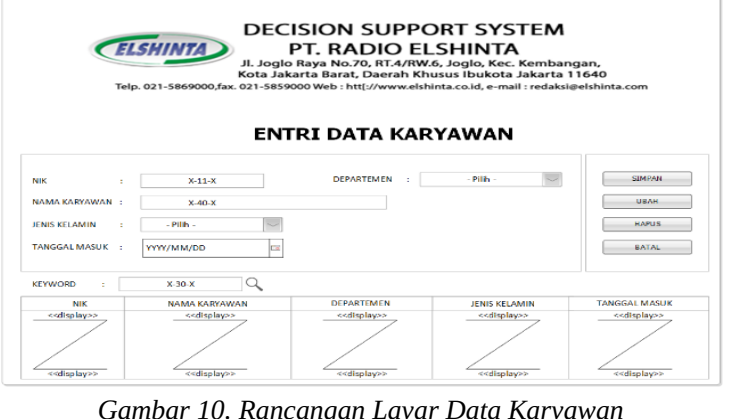

Form Entry nilai karyawan (Gambar 11) terdapat pada menu proses dibagian menu utama, form ini digunakan untuk menginput nilai karyawan. 

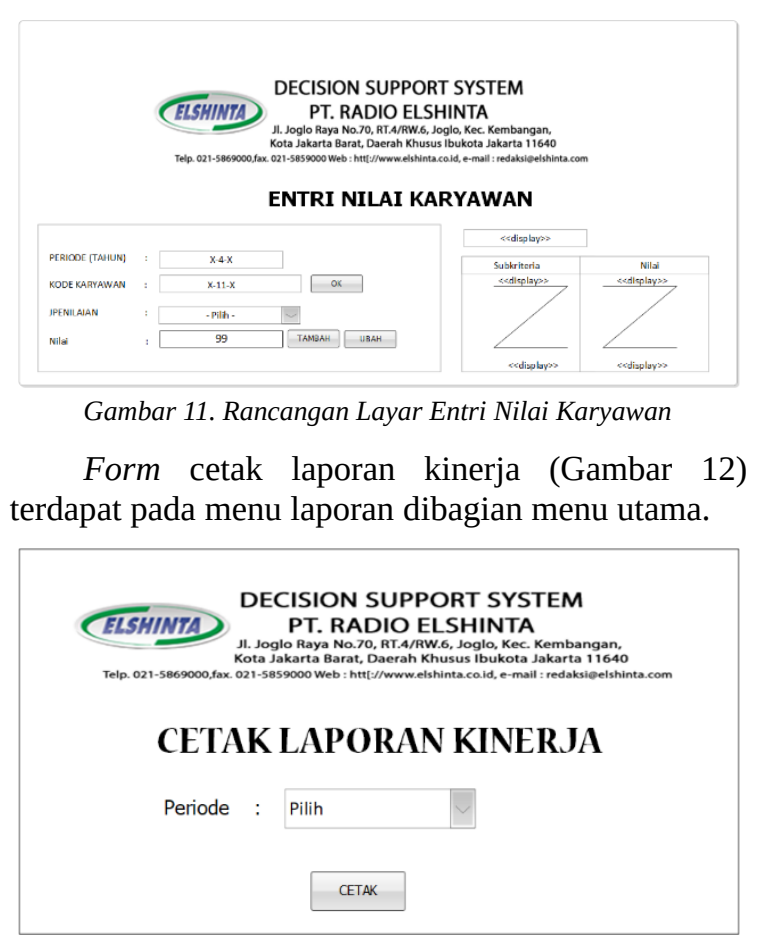

Gambar 12. Rancangan Layar Cetak Laporan Kinerja

\subsection{Hasil Penelitian}

Berdasarkan analisa yang dilakukan pada PT. Radio Elshinta, untuk menentukan karyawan terbaik diperlukan metode Analytical Hierarchy Process (AHP), maka didapatkan nilai dari setiap karyawan pada tabel 8 .

Tabel 8. Perangkingan Karyawan

\begin{tabular}{lll}
\hline Rank & Nama Karyawan & Nilai Akhir \\
\hline 1 & Oddy Yudha Pratama & 0,4101 \\
2 & Jaenal Abidin & 0,4085 \\
3 & Arief Anditantyo & 0,4084 \\
4 & Setiadi Agung Sukarno & 0,3908 \\
5 & Zukri Akmal & 0,3821 \\
\hline
\end{tabular}

Dari 5 (lima) karyawan yang ada, Oddy Yudha Pratama memiliki nilai 0,4101 dan merupakan nilai yang paling tinggi dibandingkan dengan yang lainnya

\section{KESIMPULAN}

Dengan adanya sistem penunjang keputusan ini maka dapat dilakukan proses perangkingan dalam pemilihan karyawan terbaik dengan tepat menggunakan Analytical Hierarchy Proces (AHP) sehingga proses penilaian dan pemilihan karyawan menjadi lebih tepat.

Sistem penunjang keputusan pemilihan karyawan terbaik yang telah dibangun, dapat mempermudah manajer dalam mengolah nilai karyawan sesuai dengan metode yang diterapkan, dan mempermudah dalam mengakses data-data yang diperlukan. Karena sistem yang dibangun telah terkomputerisasi yaitu berbasis desktop dan menggunkan database dalam penyimpanan data.

\section{DAFTAR PUSTAKA}

[1] Wulandari, N. E., 'Sistem Pendukung Keputusan Penentu Karyawan (Agen)Terbaik Menggunakan Metode Analytical Hierarchy Process ( Ahp ) ( Study Kasus : Kantor Cabang Ajb Bumiputera 1912 Lubuk Pakam )', 9(3), pp. 178-189, 2015.

[2] Firdaus, I. H., Abdillah, G. and Renaldi, F., 'Sistem Pendukung Keputusan Penentuan Karyawan Terbaik', 2016(Sentika), pp. 440-445, 2016.

[3] Muhaimin Hasanudin, Yansen Marli, B. H., 'Sistem Pendukung Keputusan Pemilihan Karyawan Terbaik Menggunakan Metode Analytical Hierarchy Process ( Studi Kasus Pada Pt . Bando Indonesia )', 6(3), pp. 91-96, 2018.

[4] Marbun, M. and Bosker Sinaga (2018), "Buku Ajar Sistem Pendukung Keputusan Penilaian Hasil Belajar | 1 STMIK Pelita Nusantara Medan.”, Naetty Siahaan and Tince Flora Manurung, Medan, CV. Rudang Mayang, 2018. 